EFEKTIVITAS EKSTRAK DAUN SIRSAK (Annona muricata) DAN LATIHAN FISIK SERTA KOMBINASI TERHADAP KADAR MALONDIALDEHID HEPAR PADA MODEL TIKUS HIPERKOLESTEROLEMIA-DIABETES JURNAL KESEHATAN

http://ejournal.poltekkesternate.ac.id/ojs

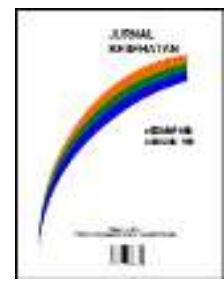

EFEKTIVITAS EKSTRAK DAUN SIRSAK (Annona muricata) DAN LATIHAN FISIK SERTA KOMBINASI TERHADAP KADAR MALONDIALDEHID HEPAR PADA MODEL TIKUS HIPERKOLESTEROLEMIA-DIABETES

\author{
Retno Yulianti $^{1 \bowtie}$, Riezky Valentina Astari ${ }^{2}$ \\ ${ }^{1}$ Departemen Patologi Anatomi, FK Universitas Pembangunan Nasional Veteran Jakarta, \\ Indonesia \\ ${ }^{2}$ Departemen Neurologi, FK Universitas Pembangunan Nasional Veteran Jakarta, Indonesia \\ ${ }^{1}$ retno.yulianti@upnvj.ac.id
}

\begin{tabular}{ll}
\hline Info Artikel & Abstrak \\
\cline { 2 - 3 } $\begin{array}{l}\text { Sejarah Artikel: } \\
\text { Diterima }\end{array}$ & $\begin{array}{l}\text { Diabetes menyebabkan kerusakan jaringan akibat hiperglikemia dan } \\
\text { Diperkolesterolemia. Stres oksidatif dapat menyebabkan peroksidasi lipid yang }\end{array}$ \\
Disetujui & dinilai melalui kadar malondialdehid. Modifikasi gaya hidup dengan latihan \\
Di Publikasi & fisik meningkatkan ambilan glukosa dan menurunkan profil lipid. Ekstrak daun \\
& sirsak berpotensi menurunkan kadar Malondialdehyde. Penelitian ini bertujuan \\
Keywords: & untuk mengetahui efek ekstrak daun sirsak dan latihan fisik serta kombinasi \\
Annona muricata, & terhadap kadar Malondialdehid hepar tikus diabetik. Tiga puluh ekor tikus putih \\
hiperkolesterolemia- & jantan galur Wistar, dikelompokkan menjadi enam kelompok yaitu: pakan \\
diabetes, latihan fisik, & standar dan aquades (K1), pakan tinggi lemak dan metformin 45mg/kgBB/hari \\
MDA & (K2), pakan tinggi lemak dan vitamin E 150 IU/kgBB/hari (K3), pakan tinggi \\
& lemak dan latihan fisik sedang 20 m/menit (K4), pakan tinggi lemak dan ekstrak \\
& daun sirsak 150 mg/kgBB/hari (K5), pakan tinggi lemak dan kombinasi (K6). \\
& Ekstrak daun sirsak diberikan selama 21 hari setelah diinduksi aloksan dan \\
& pakan tinggi lemak selama 5 minggu. Analisis data menggunakan uji One Way \\
& ANOVA dan dilanjutkan dengan uji Post Hoc LSD. Pada kelompok K6 mampu \\
& menurunkan gula darah puasa 70.97\% dan kolesterol 62.47\% dan bermakna \\
& dalam menurunkan kadar Malondialdehyde 0,9 $\mu$ Mol. Kesimpulan adalah \\
& kombinasi ekstrak daun sirsak dan latihan fisik memiliki kemampuan \\
& menurunkan kadar Malondialdehyde jaringan hepar.
\end{tabular}

THE EFFECTIVENESS OF SOURSOP LEAF EXTRACT (Annona muricata) AND PHYSICAL EXERCISE AND COMBINATION ON MALONDIALDEHID LEVELS OF HEPAR IN HYPERCOLESTEROLEMIA-DIABETES RATING MODELS

Abstract
Diabetic can cause tissue damage due to hyperglycemia and
hypercholesterolemia. Oxidative stress can cause lipid peroxidation produced
through malondialdehyde levels. Lifestyle modification by increasing physical
exercise get and decrease lipid profile. Soursop leaf extract is rejected to
decrease Malondialdehyde levels. This study discusses soursop leaf extract and
physical exercise as well as a combination of levels of liver Malondialdehyde
in diabetic rats. Thirty male white Wistar rats, grouped into six groups with
different differentiators, namely: standard feed and aquades (K1), high-fat feed
and metformin 45mg/kgBW/day (K2), high-fat feed and vitamin E 150
IU/kgBW/day (K3), high-fat feed and moderate physical exercise $20 \mathrm{~m} / \mathrm{minute}$




\section{EFEKTIVITAS EKSTRAK DAUN SIRSAK (Annona muricata) DAN LATIHAN FISIK SERTA KOMBINASI TERHADAP KADAR MALONDIALDEHID HEPAR PADA MODEL TIKUS HIPERKOLESTEROLEMIA-DIABETES}

(K4), high-fat feed and soursop leaf extract $150 \mathrm{mg} / \mathrm{kgBW} /$ day (K5), high-fat feed and combination (K6). Soursop leaf extract is given for 21 days after induction of alloxan and high-fat feed for 5 weeks. Data analysis used the One Way ANOVA test and continued with the Post Hoc LSD test. In the K6 group it was able to reduce fasting blood sugar $70.97 \%$ and cholesterol $62.47 \%$ and positive cholesterol in Malondialdehyde levels $0.9 \mu \mathrm{Mol}$. The conclusion of this study is the combination of soursop leaf extract and physical exercise has the ability to reduce levels of liver tissue Malondialdehyde.

(C) 2017 Poltekkes Kemenkes Ternate

\footnotetext{
Alamat korespondensi:

Fakultas Kedokteran Universitas Pembangunan Nasional Veteran Jakarta , Indonesia Email: retno.yulianti@upnvj.ac.id
}

ISSN 2597-7520

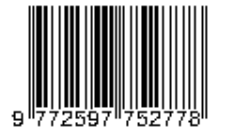

\section{Pendahuluan}

Diabetes melitus (DM) tipe 2 adalah penyakit gangguan metabolic yang disebabkan karena gangguan sekresi sel-sel pankreas atau gangguan kerja insulin dan ditandai dengan hiperglikemia dan hieprkolesterolemia. Diabetes Melitus tipe 2 menjadi masalah kesehatan masyarakat secara global dan menurut estimasi International Diabetes Federation (IDF) pada tahun 2015, jumlah penderita DM yang terjadi pada orang dewasa sekitar 415 juta. Berdasarkan hasil riset Badan Penelitian dan Pengembangan Kesehatan (2013), DM di Indonesia menduduki posisi keempat sebagai penyakit yang tidak menular dan prevalensinya meningkat dari tahun 2007 sekitar 1,1 persen menjadi 2,1 persen pada tahun 2013 (PERKENI, 2015).

Untuk menurunkan angka kejadian dan keparahan DM tipe 2 dapat melalui pola gaya hidup sehat dengan memodifikasi aktivitas fisik dengan pengobatan obat antidiabetik yang dapat meningkatkan sensistivitas perifer terhadap glukosa (PERKENI, 2015). Pada penelitian yang dilakukan oleh Wang \& $\mathrm{Xu}$ (2017) meskipun menunjukkan belum sepenuhnya diketahui adanya pengaruh latihan fisik terhadap lipid, namun latihan fisik akan meningkatkan konsumsi otot rangka terhadap lipid serta menurunkan profil lipid melalui metode peningkatan aktivitas enzim lipoprotein lipase, peningkatan ATP Binding Cassete Transport A-1 (ABCA1) yang ada kaitannya dengan pembentukkan kolesterol HDL serta peningkatan liver $x$ receptor (LXR) yang akan meningkatkan ambilan kolesterol oleh hepar. Hal ini didukung oleh penelitian yang dilakukan oleh Indriyani (2010) bahwa otot yang aktif bergerak tidak memerlukan insulin untuk memasukan glukosa ke dalam sel, selain itu latihan fisik akan menyebabkan ambilan glukosa meningkat 7-20 kali lipat.

Penyandang DM memiliki kerentanan kerusakan pada organ hati karena organ hati penting dalam memelihara kadar glukosa darah dalam batas normal, sehingga jika terjadi hiperglikemia dapat menyebabkan ketidak seimbangan reaksi oksidasi dan reduksi di hepatosit (Lailatul Fitria, Lyrawati, \& Handaru, 2015). Akibatnya, menyebabkan stres oksidatif yang dapat meningkatkan pembentukkan radikal bebas di dalam mitokondria. Radikal bebas tersebut bereaksi dengan poly unsaturated fatty acid menyebabkan peroksidasi lemak pada membran sel. Reaksi ini terjadi secara berantai yang hasil akhirnya terbentuk produk aldehid yang bersifat toksik terhadap sel yakni salah satunya adalah malondialdehid (MDA) (Marks et al., 2015).

Stres oksidatif terjadi apabila kecepatan pembentukan Reactive Oxygen Species (ROS) melebihi kemampuan sel untuk menyingkirkan radikal bebas karena sel memiliki mekanisme untuk melindungi diri dari ROS yaitu dengan enzim antioksidan. Antioksidan dapat ditemukan pada vitamin seperti vitamin C dan vitamin E (Marks et al, 2015). Selain dari vitamin, antioksidan dapat pula ditemukan pada tanaman salah satunya pada tanaman sirsak. Daun sirsak diketahui 
EFEKTIVITAS EKSTRAK DAUN SIRSAK (Annona muricata) DAN LATIHAN FISIK SERTA KOMBINASI TERHADAP KADAR MALONDIALDEHID HEPAR PADA MODEL TIKUS HIPERKOLESTEROLEMIA-DIABETES

memiliki potensi sebagai antioksidan sehingga dimanfaatkan sebagai tanaman herbal oleh beberapa peneliti (Nunung Kurniasih, 2015).

Keluhan efek samping berupa hipoglikemia yang ditimbulkan oleh penggunaan obat antidiabetes dan biaya pengobatan yang terus menerus menyebabkan kepatuhan pasien dalam meminum obat antidiabetik menjadi menurun (Rasdianah et al., 2016). Kini banyak peneliti yang tertarik untuk mengetahui potensi daun sirsak sebagai obat anti diabetes herbal. Tomar and Sisodia (2014) menjelaskan bahwa kandungan flavonoid yang banyak terdapat pada daun Annona muricata Linn. memiliki efek terhadap aktivitas antidiabetes dan mampu menghambat enzim HMG-KoA reduktase yang dapat menurunkan kolesterol darah (Taylor, 2012) serta mampu menghambat absorbsi, meningkatkan toleransi dan ambilan glukosa di perifer dan juga merangsang pelepasan dan sensitivitas insulin (Brahmachari, 2011). Pada penelitian yang dilakukan oleh Florence et al., (2014) diketahui bahwa ekstrak daun sirsak dosis 100 $\mathrm{mg} / \mathrm{kgBB}$ dapat menurunkan MDA hepar tikus, sedangkan pada dosis $200 \mathrm{mg} / \mathrm{kgBB}$ tidak memberikan efek.

Berdasarkan hal tersebut, peneliti ingin mengetahui potensi ekstrak daun sirsak 150 $\mathrm{mg} / \mathrm{kgbb}$ dan latihan fisik serta kombinasi terhadap kadar MDA pada model tikus hiperkolesterolemia-diabetes.

\section{Metode}

Jenis penelitian true experimental dengan rancangan post test randomized control group design. Perlakuan dengan lima kali pengulangan. Sampel dari penelitian ini adalah tikus putih jantan galur Wistar (Rattus norvegicus $L_{\text {.) }}$, berat badan 150-200 gram, umur 2-3 bulan yang diperoleh dari dari Laboratorium dan Teknologi Pusat Penelitian Antar Universitas Ilmu Hayati (PPAU-IH), Institut Teknologi Bandung, Jl Ganeca no.10 Lb.Siliwangi Bandung, Jawa Barat 40132. Besar sampel sebanyak 30 ekor.

Setelah 30 ekor tikus diaklimatisasi selama 1 minggu, tikus dibagi menjadi 6 kelompok secara acak yang terdiri dari kelompok kontrol negatif dengan aquades, kontrol positif dengan metformin, kontrol positif dengan vitamin $\mathrm{E} d$ - $\alpha$-tokoferol (Natur $\mathrm{E}$ Darya-Varia $\left.{ }^{\circledR}\right)$ dengan dosis $150 \mathrm{IU} / \mathrm{kgBB} /$ hari (Putra et al., 2018) dan tiga perlakuan dengan ekstrak daun sirsak $150 \mathrm{mg} / \mathrm{kgBB} /$ hari, latihan fisik 20 meter/menit selama 45 menit dan kombinasi keduanya, masingmasing kelompok sebanyak 5 ekor dengan lima kali pengulangan. Sebagai penginduksi diabetes digunakan aloksan (Aldrich $\AA$ ) dengan dosis $125 \mathrm{mg} / \mathrm{kbBB}$ yang diberikan intraperitoneal (Bakti Gumelar, R.A. Retno Ekowati, 2017). Bahan kimia yang digunakan untuk uji kadar MDA menggunakan larutan TCA (Tri Chroloacetic Acid) 20\% dan larutan Tiobarbiturat Na $0.67 \%$. Pakan tinggi lemak yang diberikan selama percobaan mengandung 16 butir telur bebek, 2,5 kg terigu, $3 / 4 \mathrm{~kg}$ minyak kelapa, dan $1 \mathrm{~kg}$ lemak kambing.

Teknik pengumpulan data dilakukan dengan melakukan :

1. Pemeriksaan karakteristik ekstrak dengan uji fitokimia

2. Pembuatan larutan ekstrak daun sirsak dibuat dari ekstrak kental ditimbang sesuai dosis $150 \mathrm{mg} / \mathrm{kgBB} /$ hari kemudian dilarutkan dengan $\mathrm{CMC} \mathrm{Na} 1 \%$.

3. Pemberian perlakuan tersebut yaitu: kelompok kontrol negatif/normal (K1) tikus diberi pakan standar dan aquades; kelompok kontrol positif (K2) tikus diberikan pakan tinggi lemak, aloksan $125 \mathrm{mg} / \mathrm{kgBB}$ dan metformin; kontrol positif (K3) tikus diberikan pakan tinggi lemak, aloksan 125 $\mathrm{mg} / \mathrm{kgBB}$ dan vitamin $\mathrm{E} \alpha$-tokoferol 150 $\mathrm{IU} / \mathrm{kgBB} /$ hari dan kelompok perlakuan tikus yang diberikan pakan tinggi lemak, aloksan $125 \mathrm{mg} / \mathrm{kgBB}$ dan ekstrak daun sirsak 150 $\mathrm{mg} / \mathrm{kgBB} / \mathrm{hari}$ (K4); latihan fisik 20 meter/menit selama 45 menit (K5) dan kombinasi antara ekstrak daun sirsak 150 $\mathrm{mg} / \mathrm{kgBB} / \mathrm{hari}$ dengan latihan fisik 20 meter/menit selama 45 menit (K6).

4. Pemberian pakan tinggi lemak pada kelompok K2, K3, K4, K5 dan K6 dilakukan selama 5 minggu kemudian dilanjutkan satu kali injeksi aloksan dosis $125 \mathrm{mg} / \mathrm{kgBB}$ secara peritoneal, lalu ditunggu efeknya selama 72 jam. Setelah dinyatakan hiperglikemia, semua kelompok tikus (K2 sampai K6) diberikan perlakuan sesuai masing-masing kelompok dan pakan standar 
EFEKTIVITAS EKSTRAK DAUN SIRSAK (Annona muricata) DAN LATIHAN FISIK SERTA KOMBINASI TERHADAP KADAR MALONDIALDEHID HEPAR PADA MODEL TIKUS HIPERKOLESTEROLEMIA-DIABETES

selama tiga minggu.

Kadar glukosa darah puasa dan kolesterol tikus diukur sebanyak dua kali, yakni 72 jam setelah injeksi aloksan dan sesaat sebelum terminasi, dinyatakan diabetes jika glukosa darah puasa $\geq 135 \mathrm{mg} / \mathrm{dL}$ (Esmawati, 2015) dan hiperkolesterolemia jika kolesterol total lebih dari $54 \mathrm{mg} / \mathrm{dL}$ ((Diajeng Galuh Riesanti, Masdiana C Padaga, 2012). Pengukuran kadar gula darah puasa menggunakan darah yang diambil dari vena caudalis pada ujung ekor tikus. Sebelum pengambilan darah, ekor tikus dicelupkan pada air hangat lalu dengan menggunakan skapel ekor tikus dipotong. Darah diambil secukupnya lalu diteteskan ke alat glukometer. Data tersebut kemudian dicatat dan dianalisis secara statistik.

Pada minggu pertama perlakuan latihan fisik, dilakukan adaptasi terlebih dahulu dengan treadmill yang diberikan kecepatan 5 meter/menit selama 15 menit, kemudian dilanjutkan treadmill selama 2 minggu dengan kecepatan bertingkat yakni, tiga hari awal akan dilakukan treadmill secara bertahap dengan kecepatan 10 meter/menit, 11 meter/menit dan 12 meter/menit selama 30 menit lalu berikutnya kecepatan makin meningkat pada empat hari berikutnya, dilakukan treadmill dengan kecepatan 20 meter/menit selama 30 menit dan satu minggu terakhir dilanjutkan kembali dengan kecepatan 20 meter/menit selama 45 menit (Souza et al., 2007).

Pada akhir perlakuan semua kelompok tikus dilakukan terminasi yang terlebih dahulu dianestesi menggunakan ketamin 0.3 $\mathrm{mL}$ secara intramuskular sampai tikus tidak sadar, selanjutnya dilakukan terminasi dengan metode dislokasi servikal. Setelah itu dilakukan pembedahan dan pengambilan organ hati yang selanjutnya dilakukan perhitungan kadar MDA.

5. Pengukuran kadar MDA organ hati dilakukan dengan cara menimbang $10 \mathrm{mg}$ jaringan hati lalu dihomogenasi di dalam tabung appendorf. Sampel hepar ditambahkan $1 \mathrm{~mL}$ akuades. Pemeriksaan MDA dilakukan dengan penambahan Thiobarbituric acid (TCA) $20 \% 200 \mu \mathrm{L}$ dengan homogenate 400 $\mu \mathrm{L}$. Kemudian campuran divortex hingga terlihat keruh lalu disentrifugasi pada Jurnal Kesehatan Published By Poltekkes Ternate, 13, (1), 2020, Pages, 11 - 18 kecepatan $5000 \mathrm{rpm}$ selama 10 menit. Supernatant dari campuran tersebut diambil dan ditambahkan $400 \mu \mathrm{L}$ larutan tiobarbiturat 0,67\% kemudian panaskan dalam $95-100{ }^{\circ} \mathrm{C}$ selama 10 menit lalu didinginkan.Sampel yang telah dingin dimasukkan dalam kuvet lalu diukur dengan spektrofotometri pada panjang gelombang $530 \mathrm{~nm}$ (Lailatul Fitria et al., 2015). Hasil pemeriksaan berupa nilai serapan yang kemudian dihitung kadar MDA menggunakan kurva standar, selanjutnya data dianalisis dengan menggunakan SPSS 16 dengan tingkat signifikansi 0,05 dan taraf kepercayaan $95 \%(\alpha=0,05)$.

\section{Analisa Data}

Setelah pengambilan data, data dianalisis menggunakan uji One way Annova untuk mengetahui apakah terdapat perbedaan kadar MDA pada semua kelompok. Selanjutnya untuk mengatahui letak perbedaan yang bermakna pada masing-masing kelompok dilakukan analisis post-hoc multiple comparison test.

\section{Hasil dan Pembahasan}

Hasil uji fitokimia ekstrak daun sirsak diketahui bahwa ekstrak yang digunakan dalam penelitian terbukti mengandung senyawa antioksidan flavonoid (Tabel 1) yang berperan sebagai antioksidan dengan cara membersihkan oksidan secara langsung dengan bereaksi bersama ROS sehingga terbentuk radikal yang lebih stabil dan tidak reaktif (Panche, AN, Diwan, AD, Chandra, 2016).

Tabel 1 Hasil Uji Fitokimia Ekstrak Daun Sirsak

\begin{tabular}{cc}
\hline Uji Fitokimia & Hasil Uji \\
\hline Flavonoid & + \\
\hline Saponin & + \\
\hline Tanin & + \\
\hline Fenolik & + \\
\hline Triterpenoid & + \\
\hline Steroid & + \\
\hline Glikosida & + \\
\hline Alkaloid & + \\
\hline
\end{tabular}

Sumber : Data primer

Senyawa quercetin, satu jenis flavonoid dari subkelas flavonol, memiliki potensi sebagai agen hipoglikemik melalui mekanisme penghambatan terhadap enzim alfa amilase 
EFEKTIVITAS EKSTRAK DAUN SIRSAK (Annona muricata) DAN LATIHAN FISIK SERTA KOMBINASI TERHADAP KADAR MALONDIALDEHID HEPAR PADA MODEL TIKUS HIPERKOLESTEROLEMIA-DIABETES

yang berperan dalam pemecahan karbohidrat (Iyos \& Astuti, 2013). Selain itu senyawa tanin yang terkandung dalam daun sirsak melalui aktivasi MAPK (Mitogen- Activated Protein Kinase) dan PI3K (Phosphoinositide 3-Kinase) mampu menurunkan kadar gula darah. Hasil hidrolisis tanin berupa gallotanin dan ellagitanin. Keduanya memiliki kerja yang berbeda dalam menurunkan kadar gula darah, gallotanin dengan cara meningkatkan ambilan glukosa serta menghambat adipogenesis, sedangkan ellagitanin memiliki sifat seperti hormon insulin yang dapat meningkatkan aktivitas transport glukosa ke dalam sel adiposa secara in vitro (Iyos \& Astuti, 2013). Dari Tabel 2 terlihat rerata kadar glukosa darah puasa tikus pada semua kelompok perlakuan setelah pemberian aloksan mengalami peningkatan kadar glukosa puasa dari nilai normal $\geq 135 \mathrm{mg} / \mathrm{dL}$ (Esmawati, 2015).

Tabel 2 Rerata Penurunan Kadar Gula Darah Puasa (GDP)

\begin{tabular}{cc}
\hline Kelompok & $\begin{array}{c}\text { Rerata Penurunan } \\
\text { Kadar GDP } \\
(\mathrm{mg} / \mathrm{dL}) \pm \text { SD }\end{array}$ \\
\hline $\mathrm{K} 1$ & $17.6 \pm 6.23$ \\
\hline $\mathrm{K} 2$ & $182.8 \pm 82.55$ \\
\hline $\mathrm{K} 3$ & $260.8 \pm 147.10$ \\
\hline $\mathrm{K} 4$ & $175.2 \pm 111.02$ \\
\hline $\mathrm{K} 5$ & $167.8 \pm 109.87$ \\
\hline K6 & $242 \pm 167.23$ \\
\hline Sumber D Data primer &
\end{tabular}

Hal ini dikarenakan kerja aloksan yang menyebabkan gangguan sekresi insulin sel beta pankreas melalui penghambatan enzim glukokinase, sehingga tidak terbentuk ATP dan terbukanya kanal kalium. Proses ini akan menyebabkan terhambatnya pemasukan kalsium ke dalam sel beta pankreas, sehingga tidak terjadi proses depolarisasi sel dan berdampak tidak disekresikannya insulin. Keadaan tersebut akan menyebabkan terjadinya hiperglikemia dan sebagai senyawa diabetagonik/glukomimetik, aloksan mampu menyebabkan nekrosis sel-sel pulau Langerhans pankreas. Penurunan kadar glukosa darah puasa setelah dilakukan perlakuan pada kelompok ektrak daun sirsak (K4) dan kombinasi (K6) sejalan dengan Esmawati, (2015) bahwa ekstrak daun sirsak mampu menurunkan kadar glukosa darah tikus yang diinduksi aloksan. Pada kelompok kombinasi (K6) penurunan kadar glukosa puasa lebih tinggi dibandingkan dengan kelompok ekstrak daun sirsak (K4) dan latihan fisik (K5) tetapi masih lebih rendah dari kelompok kontrol positif (K3). Hal ini karena kedua kelompok tersebut memiliki kemampuan sebagai efek hipoglikemik sehingga mampu mencegah kerusakan dari sel-sel pankreas serta ditambah latihan fisik mampu memasukan glukosa ke dalam sel dan menyebabkan ambilan glukosa meningkat 720 kali lipat.

Tabel 3 Rerata Kadar Kolesterol Total

\begin{tabular}{lcccc}
\hline & \multicolumn{3}{c}{ Kolesterol Total (mg/dL) } \\
\cline { 2 - 5 } $\begin{array}{c}\text { Kelom } \\
\text { pok }\end{array}$ & $\begin{array}{c}5 \mathrm{mgg} \\
\text { pemberi } \\
\text { an pakan } \\
\text { tinggi } \\
\text { lemak }\end{array}$ & $\begin{array}{c}3 \mathrm{mgg} \\
\text { Perlakuan }\end{array}$ & $\begin{array}{c}\text { Rerata } \\
\text { Penurunan }\end{array}$ & SD \\
\hline K1 & 154,8 & 85,96 & 68,84 & 36.65 \\
\hline K2 & 185,6 & 61,34 & 124,26 & 33.77 \\
\hline K3 & 163,8 & 72,72 & 91,08 & 26.68 \\
\hline K4 & 173,4 & 62,12 & 111,28 & 48.14 \\
\hline K5 & 199,4 & 69,82 & 129,58 & 80.24 \\
\hline K6 & 181,4 & 68,08 & 113,32 & 29.02 \\
\hline Sumber : Data primer & & \\
\hline
\end{tabular}

Penelitian ini menggunakan tikus jantan sehingga pemeriksaan kadar kolesterol total tidak terpengaruh oleh hormonal meskipun hewan tersebut memiliki sedikit estrogen. Pemberian lipid tinggi menyebabkan penimbunan lemak dalam hepar yang akan berdampak pada peningkatan jumlah acetil co-A dalam sel hepar untuk menghasilkan kolesterol. Lemak jenuh mengakibatkan kadar trigliserida dalam darah meningkat dan merupakan precursor kolesterol. Mengkonsumsi lemak jenuh menyebabkan peningkatan kadar kolesterol total dan penurunan HDL, sehingga konsumsi lemak berlebihan akan berefek pada terjadinya hiperkolesterolemia yang ditandai dengan meningkatnya ApoB kolesterol dan kadar LDL (Harini, Marti and Astirin, 2009). Untuk pengukuran kolesterol darah tikus menggunakan induksi diet tinggi lemak dan aloksan sehingga menjadi model hiperkolesterolemia-diabetes. Pada tikus $R$. norvegicus. galur Wistar, kadar kolesterol darah normal adalah 10-54 $\mathrm{mg} / \mathrm{dl}$. Keberhasilan induksi diet tinggi lemak 
EFEKTIVITAS EKSTRAK DAUN SIRSAK (Annona muricata) DAN LATIHAN FISIK SERTA KOMBINASI TERHADAP KADAR MALONDIALDEHID HEPAR PADA MODEL TIKUS HIPERKOLESTEROLEMIA-DIABETES

terlihat dari rerata penurunan kolesterol total antara kelompok kontrol negatif (normal) dengan kelompok lainnya yang cenderung lebih rendah $(68.84 \mathrm{mg} / \mathrm{dL} \pm \mathrm{SD} 36.65)$ seperti terlihat pada Tabel 3. Pengaruh pemberian pada semua perlakuan baik pemberian vitamin $\mathrm{E}$, metformin, ekstrak daun sirsak $150 \mathrm{mg} / \mathrm{kgBB}$, latihan fisik sedang 20 meter/menit selama 45 menit maupun kombinasi terlihat kecenderungan menunjukkan penurunan kadar kolesterol total, namun tidak berbeda nyata. Penurunan tertinggi pada kelompok latihan fisik, sedangkan pada 3 kelompok perlakuan ternyata juga tidak menunjukkan perbedaan yang nyata. Dapat disimpulkan bahwa semua kelompok perlakuan belum dapat menurunkan kadar kolesterol total hiperkolesterol diabetik secara signifikan.

Kelompok kontrol positif menunjukkan aktivitas penurunan kolesterol total yang berbeda nyata jika dibandingkan dengan kelompok kontrol negatif (normal). Hal ini sesuai dengan sifat efek metabolik metformin terhadap diabetes melitus sebagai antidiabetik dan dalam metabolisme lipid yang mampu menurunkan kolesterol total. Meskipun mekanisme kerja dari metformin belum diketahui pasti, namun diduga memperbaiki resistensi insulin dan mampu meningkatkan jumlah reseptor insulin (Nurwahyunani, A.,2006).

Tabel 4 Rerata Kadar MDA Hepar Tikus

\begin{tabular}{cc}
\hline Kelompok & $\begin{array}{c}\text { Kadar MDA } \pm \text { SD } \\
(\text { nmol/dL } \pm \text { SD })\end{array}$ \\
\hline K1 & $0,11 \pm 0,0527$ \\
\hline K2 & $0,14 \pm 0,1122$ \\
\hline K3 & $0,15 \pm 0,0813$ \\
\hline K4 & $0,12 \pm 0,0097$ \\
\hline K5 & $0,10 \pm 0,0514$ \\
\hline K6 & $0,12 \pm 0,0458$ \\
\hline
\end{tabular}

Sumber : Data primer

Pada Tabel 4 menunjukkan hasil penghitungan kadar MDA hepar masingmasing kelompok yang dinilai menggunakan alat spektrofotometer UV-Vis. Pada kelompok kontrol negatif (K1) yang hanya diberikan pakan standar dan aquades memiliki kadar MDA rendah $(0.11 \mathrm{nmol} / \mathrm{mL})$, namun kadar MDA kelompok perlakuan paling rendah dimiliki kelompok $\mathrm{K} 5$ yaitu $0.10 \mathrm{nmol} / \mathrm{mL}$, sedangkan kadar MDA pada kelompok perlakuan $\mathrm{K} 2(0.14 \mathrm{nmol} / \mathrm{mL})$ dan $\mathrm{K} 3(0.15$ $\mathrm{nmol} / \mathrm{mL}$ ) cukup tinggi jika dibandingkan dengan kelompok K4, K5 dan K6 yang tidak jauh berbeda nyata.

Diketahui hiperglikemia menyebabkan peningkatan ROS yang berakibat terjadinya peroksidasi lipid dan menyebabkan peningkatan kadar MDA. Hal ini terlihat kadar MDA pada kelompok K4, K5 dan K6 yang lebih rendah dibandingkan dengan K2 dan K3. Hasil penelitian ini sesuai dengan teori oleh Marks et al., (2015) yang menjelaskan bahwa peroksidasi lipid merupakan perombakan lipid yang menghasilkan produk salah satunya MDA. Peroksidasi lipid dapat merusak fungsi sel pada mitokondria, berawal dari kerusakan membran sel akan menyebabkan gangguan fluiditas membran yang bertanggung jawab terhadap integritas dan transpor membran, serta juga dapat menyebabkan inaktivasi pompa membran sehingga ketiadaan ATP akan mempengaruhi kelangsungan hidup dari sel dan dapat menyebabkan kematian sel (Neha Wadhwa, Blessy B Mathew, 2012). Pada kelompok yang diberikan vitamin $\mathrm{E} \alpha$ tokoferol tidak lebih efektif untuk menurunkan kadar MDA dibandingkan pemberian ekstrak daun sirsak dosis 150 $\mathrm{mg} / \mathrm{kgBB} /$ hari, latihan fisik serta kombinasi karena ekstrak daun sirsak yang tidak mudah bereaksi dengan senyawa lain termasuk lipid dalam membran sel. Keadaan tersebut menyebabkan tidak terjadinya peroksidasi lipid sehingga menurunkan produksi kadar MDA. Penurunan kadar MDA oleh vitamin E $\alpha$-tokoferol disebabkan karena vitamin E akan menyumbangkan atom hidrogen, dan akan bereaksi dengan oksigen reaktif, sehingga kadar ROS berkurang (Sabrina Aprilisa Martha, 2013)

Penurunan kadar hiperglikemik dan rendahnya nilai kadar MDA pada kelompok $\mathrm{K} 4$, ini sejalan dengan penelitian Esmawati, (2015) menunjukan bahwa pemberian ekstrak daunsirsak dosis $150 \mathrm{mg} / \mathrm{kgBB}$ pada tikus model diabetik yang diinduksi aloksan memberikan efek perbaikan sel-sel pankreas dan penurunan kadar glukosa secara efektif.

Florence et al., (2014) dan Adewole \& Ojewole (2009), menyatakan bahwa kandungan flavonoid pada ekstrak daun sirsak 
EFEKTIVITAS EKSTRAK DAUN SIRSAK (Annona muricata) DAN LATIHAN FISIK SERTA KOMBINASI TERHADAP KADAR MALONDIALDEHID HEPAR PADA MODEL TIKUS HIPERKOLESTEROLEMIA-DIABETES

akan bereaksi dengan ROS yang terbentuk akibat keadaan hiperglikemik, kemudian flavonoid akan memberikan 1 atom hidrogennya kepada ROS sehingga radikal tersebut menjadi lebih stabil dan tidak mudah bereaksi dengan senyawa lain termasuk lipid dalam membran sel, sehingga menyebabkan tidak terjadinya peroksidasi lipid dan tidak terbentuk MDA, sehingga kadar MDA menurun (Panche, AN, Diwan, AD, Chandra, 2016).

Menurut Florence et al., (2014) bahwa pemberian ekstrak daun sirsak dosis sedang yaitu $100 \mathrm{mg} / \mathrm{kgBB}$ lebih efektif dibandingkan $200 \quad \mathrm{mg} / \mathrm{kgBB}$ untuk menurunkan kadar MDA hepar tikus diabetik diduga karena efek sitotoksik, Pada penelitian Alphonse S et al, (2018) didapatkan hasil bahwa pemberian ekstrak daun sirsak 200 $\mathrm{mg} / \mathrm{kgBB}$ selama 14 hari memberikan gambaran kerusakan pada inti sel hepatosit, sedangkan penelitian Putra et al., (2018) menyatakan bahwa ekstrak daun sirsak dengan dosis lebih dari $250 \mathrm{mg} / \mathrm{kgBB}$ memiliki efek sitotoksik. Pada penelitian Lemmens et al.,(2014) flavonoid yang teroksidasi akan menghasilkan metabolit yang dapat merusak antioksidan glutathione (GSH), sehingga diduga terjadi penurunan kerja antioksidan intrasel yang menyebabkan kadar ROS di hepar masih tetap tinggi.

\section{Penutup}

Pemberian latihan fisik menunjukkan hasil kadar MDA yang lebih rendah dibandingkan dengan kelompok kontrol positif.meskipun tidak terdapat perbedaan pada kelompok ekstrak daun sirsak (Anonna muricata) $150 \mathrm{mg} / \mathrm{KgBB} /$ hari dan kombinasi serta vitamin $\mathrm{E}$.

\section{Ucapan Terima Kasih}

Ucapan terima kasih ditujukan kepada Lembaga Penelitian dan Pengabdian Masyarakat Universitas Pembangunan Nasional Veteran Jakarta yang telah mendanai penelitian internal ini.

\section{Daftar Pustaka}

Adewole, S. O., \& Ojewole, J. A. O. (2009). Protective effects of Annona muricata Linn.
(Annonaceae) leaf aqueous extract on serum lipid profiles and oxidative stress in hepatocytes of streptozotocin-treated diabetic rats. African Journal of Traditional, Complementary and Alternative Medicines. https://doi.org/10.4314/ajtcam.v6i1.57071

Alphonse S et al. (2018). Evaluation of the toxicity of Annona muricata leaf extracts on liver and kidney function and investigation of acute and subacute toxicity in Wistar rats. Am. J. PharmTech Res., 8(1). Retrieved from www.ajptr.com

Badan Penelitian dan Pengembangan Kesehatan. (2013). Riset Kesehatan Dasar (RISKESDAS) 2013. Laporan Nasional 2013, 1-384. https://doi.org/1 Desember 2013

Bakti Gumelar, R.A. Retno Ekowati, A. R. F. (2017). Potensi Ekstrak Etanol Daun Sirsak (Annona muricata) sebagai Agen Terapi Hiperglikemia pada Mencit yang Diinduksi AloksanNo Title. Bandung Meeting on Global Medicine \& Health (BaMGMH), 1 No.1.

Brahmachari, G. (2011). Bio-flavonoids with promising anti- diabetic potentials : A critical survey. Opportunity, Challenge and Scope of Natural Products in Medicinal Chemistry - Research Signpost.

Diajeng Galuh Riesanti, Masdiana C Padaga, H. (2012). No TitKadar HDL, Kadar LDL dan Gambaran Histopatologi Aorta Pada Hewan Model Tikus (Rattus norvegicus) Hiperkolesterolemia Dengan Terapi Ekstrak Air Benalu Mangga (Dendrophthoe pentandra)le. FKH UB. Retrieved from https://fkh.ub.ac.id/wpcontent/uploads/2012/10/0911310008DiajengGaluhR.pdf

Esmawati, E. (2015). Pengaruh ekstrak daun sirsak (Annona muricata L.) terhadap kadar glukosa darah dan histologi pankreas tikus (Rattus norvegicus) yang diinduksi aloksan (Maulana Malik Ibrahim State Islamic University). Retrieved from http://etheses.uin-malang.ac.id/446/

Florence, N. T., Benoit, M. Z., Jonas, K., Alexandra, T., Désiré, D. D. P., Pierre, K., \& Théophile, D. (2014). Antidiabetic and antioxidant effects of Annona muricata (Annonaceae), aqueous extract on streptozotocin-induced diabetic rats. Journal of Ethnopharmacology. https://doi.org/10.1016/j.jep.2013.09.021

Harini, Marti and Astirin, O. P. (2009). Blood cholesterol levels of hypercholesterolemic rat (Rattus norvegicus) after VCO treatment. Nusantara Bioscience. 
EFEKTIVITAS EKSTRAK DAUN SIRSAK (Annona muricata) DAN LATIHAN FISIK SERTA KOMBINASI TERHADAP KADAR MALONDIALDEHID HEPAR PADA MODEL TIKUS HIPERKOLESTEROLEMIA-DIABETES

https://doi.org/10.13057/nusbiosci/n010201

Indriyani, P. S. (2010). PENGARUH LATIHAN

FISIK; SENAM AEROBIK TERHADAP PENURUNAN KADAR GULA DARAH PADA PENDERITA DM TIPE 2 DI WILAYAH PUSKESMAS BUKATEJA PURBALINGGA. Nurse Media: Journal of Nursing. https://doi.org/10.14710/nmjn.v1i2.717

Iyos, R. N., \& Astuti, P. D. (2013). Pengaruh Ekstrak Daun Sirsak (Annona muricata L.) terhadap Penurunan Kadar Glukosa Darah. Majority.

Lailatul Fitria, N., Lyrawati, D., \& Handaru, M. (2015). Efek Pemberian Asam Alfa Lipoat terhadap Kadar MDA dan Gambaran Histologi pada Hati Tikus Wistar Jantan dengan Diabetes Melitus Tipe 1. Jurnal Kedokteran Brawijaya. https://doi.org/10.21776/ub.jkb.2015.028.03. 2

Lemmens, K. J. A., Vrolijk, M. F., Bouwman, F. G., van Der Vijgh, W. J. F., Bast, A., \& Haenen, G. R. M. M. (2014). The minor structural difference between the antioxidants quercetin and 4'Omethylquercetin has a major impact on their selective thiol toxicity. International Journal of Molecular Sciences. https://doi.org/10.3390/ijms15057475

Marks, D. B., Marks, A. D., \& Smith, C. M. (2015). Biokimia Kedokteran Dasar. EGC.

Neha Wadhwa, Blessy B Mathew*, S. K. J. and A. T. (2012). Lipid peroxidation: Mechanism, models and significance. INT J CURR SCI, 3, 29-38. Retrieved from https://www.researchgate.net/profile/Blessy_ Mathew5/publication/262176367_Lipid_per oxidation_mechanism_models_and_signific ance_International_Journal_of_Current_Scie nce_2012_3_1117/links/0deec53704e7d36b65000000.pdf

Nunung Kurniasih. (2015). Potensi Daun Sirsak (Annona muricata Linn), Daun Binahong ( Anredera cordifolia (Ten) Steenis), dan Daun Benalu Mangga (Dendrophthoe pentandra) Sebagai Antioksidan Pencegah Kanker. Jurnal ISTEK, 9 No.1. Retrieved from https://journal.uinsgd.ac.id/

Panche, AN, Diwan, AD, Chandra, S. (2016). Flavonoids: An overview. Journal of Nutritional Science, 5, 1-15. https://doi.org/:10.1017/jns.2016.41

PERKENI. (2015). Konsensus Pengendalian dan Pencegahan Diabetes Melitus Tipe 2 di Indonesia 201. Retrieved from https://pbperkeni.or.id/

Putra1, A. A. R., , Syafruddin2, R. D., Salim3, M.
N., Rinidar4, Erwin2, \& Fadli A Gani. (2018). Pengaruh Pemberian Vitamin E Terhadap Kadar Superoksida Dismutase Serum Tikus Putih ( Rattus norvegicus ) Diabetes Melitus. JIMVET, 2 No.4, 442449. Retrieved from http://jim.unsyiah.ac.id/ Rasdianah, N., Martodiharjo, S., Andayani, T. M., $\&$ Hakim, L. (2016). The Description of Medication Adherence for Patients of Diabetes Mellitus Type 2 in Public Health Center Yogyakarta. Indonesian Journal of Clinical Pharmacy, 5(4), 249-257. https://doi.org/10.15416/ijcp.2016.5.4.249

Sabrina Aprilisa Martha. (2013). Mekanisme kerja dan fungsi hayati vitamin D pada tumbuhan dan mamalia. Seminar Nasional X Pendidikan Biologi FKIP UNS. Retrieved from

https://media.neliti.com/media/publications/ 175606-ID-mekanisme-kerja-dan-fungsihayati-vitami.pdf

Souza, S. B. C., Flues, K., Paulini, J., Mostarda, C., Rodrigues, B., Souza, L. E., ... De Angelis, K. (2007). Role of exercise training in cardiovascular autonomic dysfunction and mortality in diabetic ovariectomized rats. Hypertension. https://doi.org/10.1161/HYPERTENSIONA HA. 107.095000

Taylor, L. (2012). Herbal secret of the rainorest: technical data report for graviola Annona muricata (Second). California: Sage Press, Inc.

Tomar, R., \& Sisodia, S. (2014). Antidiabetic activity of Annona squamosa Linn. in alloxan - induced diabetic rats. International Journal of Green Pharmacy, 8(4), 237. https://doi.org/10.4103/0973-8258.142679

Wang, Y., \& Xu, D. (2017). Effects of aerobic exercise on lipids and lipoproteins. Lipids in Health and Disease. https://doi.org/10.1186/s12944-017-0515-5 